\title{
Molecular and Genetic Mechanisms Involved in the Pathogenesis of Cardiorenal Cross Talk
}

\author{
Grazia Maria Virzi $^{a, b}$ Anna Clementi ${ }^{b, c}$ Alessandra Brocca ${ }^{a, b, d}$ \\ Massimo de Cal ${ }^{a, b} \quad$ Claudio Ronco $^{a, b}$ \\ a Department of Nephrology, Dialysis and Transplant, San Bortolo Hospital, and bIRRIV - International Renal \\ Research Institute Vicenza, Vicenza, 'Department of Nephrology and Dialysis, San Giovanni di Dio Hospital, \\ Agrigento, and ${ }^{\mathrm{d}}$ Department of Medicine (DIMED), University of Padova Medical School, Padova, Italy
}

\section{Key Words}

Cardiorenal syndrome $\cdot$ Epigenetics · Extracellular vesicles . Small noncoding RNA

\begin{abstract}
The term 'cardiorenal syndrome' (CRS) encloses a scenario of clinical interactions in which cardiac and renal dysfunctions coexist. The cross talk between the heart and the kidney is clearly evidenced but not fully understood. Indeed, different factors have been shown to be involved in the pathogenesis of CRS, such as systemic inflammation, oxidative stress, apoptosis and immune dysregulation. Recently, considerable attention has been paid to the role of new alternative mechanisms which may be implicated in the pathogenesis of cardiorenal cross talk. In this review, we will focus on epigenetics, prenatal programming, small noncoding RNAs and extracellular vesicles, aiming to elucidate their possible role in heart and kidney diseases.

(c) 2016 S. Karger AG, Basel
\end{abstract}

\section{Introduction}

Heart performance and kidney function are closely interconnected. The physiological cross talk between these two organs is necessary to maintain the regular homeostasis and the normal functioning of the human body. However, during disease states, the damaged organ can induce structural and functional dysfunction in the other organ. The term cardiorenal syndrome (CRS) encloses a scenario of clinical interactions in which cardiac and renal dysfunctions coexists. Observational and clinical data showed that acute/chronic worsening of kidney function directly contributes to acute/chronic cardiac disease and vice versa, constituting the CRS [1-4]. The CRS classification includes a huge array of acute and chronic conditions of these two systems, where the primary failing organ can be either the heart or the kidneys. The current definition has been expanded into 5 subtypes whose etymology reflects the primary and secondary pathology, the time frame, as well as cardiac and renal co-dysfunction consequent to systemic disease (table 1) [1]. Moreover, epidemiological studies of CRS indicate that patients may move between different CRS subtypes [5-7]. Systemic in-

\section{KARGER}

E-Mail karger@karger.com

www.karger.com/pat (c) 2016 S. Karger AG, Basel

1015-2008/16/0834-0201\$39.50/0
Dr. Grazia Maria Virzì

Department of Nephrology, Dialysis and Transplantation

San Bortolo Hospital, IRRIV, Via Rodolfi 37

IT-36100 Vicenza (Italy)

E-Mail graziamaria.virzi@gmail.com 
Table 1. CRS classification system

\begin{tabular}{lll}
\hline $\begin{array}{l}\text { Acute } \\
\text { cardiorenal } \\
\text { syndrome }\end{array}$ & CRS type 1 & $\begin{array}{l}\text { Abrupt worsening of cardiac function leading to acute kidney injury, e.g. acute coronary } \\
\text { syndrome, acute decompensated heart failure or cardiogenic shock causing acute heart failure } \\
\text { and then renal dysfunction }\end{array}$ \\
\hline $\begin{array}{l}\text { Chronic } \\
\text { cardiorenal } \\
\text { syndrome }\end{array}$ & CRS type 2 & $\begin{array}{l}\text { Chronic abnormalities in cardiac function causing progressive CKD, e.g. congestive cardiac and } \\
\text { chronic heart failure }\end{array}$ \\
\hline $\begin{array}{l}\text { Acute } \\
\text { renocardiac } \\
\text { syndrome }\end{array}$ & CRS type 3 & $\begin{array}{l}\text { Sudden worsening of renal function causing acute cardiac dysfunction, e.g. uremic } \\
\text { cardiomyopathy secondary to acute renal failure, acute kidney ischemia or glomerulonephritis } \\
\text { that leads to acute cardiac injury and/or dysfunction (such as acute myocardial infarction, } \\
\text { ischemia, congestive heart failure, pulmonary edema and arrhythmia) }\end{array}$ \\
\hline $\begin{array}{l}\text { Chronic } \\
\text { renocardiac } \\
\text { syndrome }\end{array}$ & CRS type 4 & $\begin{array}{l}\text { Condition of primary CKD leading to an impaired cardiac function and/or increased risk of } \\
\text { adverse cardiovascular events, e.g. left ventricular hypertrophy, diastolic heart failure secondary } \\
\text { to renal failure and extreme burden of cardiovascular disease risk in patients with CKD, such as } \\
\text { chronic glomerular disease and autosomal dominant polycystic kidney disease }\end{array}$ \\
\hline $\begin{array}{l}\text { Secondary } \\
\text { cardiorenal } \\
\text { syndrome }\end{array}$ & CRS type 5 & $\begin{array}{l}\text { Systemic disorders causing both cardiac and renal dysfunction, e.g. septic shock, vasculitis, } \\
\text { diabetes mellitus, systemic lupus erythematosus, infections, drugs, toxins and connective tissue } \\
\text { disorders }\end{array}$ \\
\hline
\end{tabular}

Table 2. Possible new mechanisms implicated in CRS cross talk

\begin{tabular}{lll}
\hline $\begin{array}{l}\text { Epigenetic } \\
\text { mechanisms }\end{array}$ & $\begin{array}{l}\text { Changes in gene function that are mitotically and/or meiotically } \\
\text { heritable and that do not entail a change in DNA sequence }\end{array}$ & $\begin{array}{l}\text { Covalent modifications of DNA } \\
\text { bases (e.g. DNA methylation) } \\
\text { Histone modification } \\
\text { RNA interference } \\
\text { Chromatin remodeling }\end{array}$ \\
\hline $\begin{array}{l}\text { Prenatal } \\
\text { programming }\end{array}$ & $\begin{array}{l}\text { Environmental cues during fetal development can permanently } \\
\text { affect the composition, homeostatic systems and functions of } \\
\text { multiple organs and systems }\end{array}$ & Nutrition for example \\
\hline $\begin{array}{l}\text { Small } \\
\text { noncoding }\end{array}$ & RNA that does not encode a protein and regulates gene expression & miRNAs \\
RNA & & $\begin{array}{l}\text { Small interfering RNAs } \\
\text { Piwi-interacting RNAs }\end{array}$ \\
\hline EVs & Cell-derived vesicles that are enclosed by a lipid bilayer, ranging & $\begin{array}{l}\text { Apoptotic bodies } \\
\text { Microvesicles }\end{array}$ \\
\hline
\end{tabular}

flammation, oxidative stress, apoptosis and immune dysregulation have been demonstrated to play a pivotal role in the pathogenesis of CRS $[1,4,8-16]$. Furthermore, new alternative mechanisms, such as epigenetics, prenatal programming, small noncoding RNAs and extracellular vesicles (EVs), have recently been proposed to be implicated in CRS (table 2). In this review, we will focus on these mechanisms, aiming to elucidate their role in the pathophysiology of heart and kidney cross talk.

\section{Epigenetics and Prenatal Programming in CRS}

Epigenetics is a relatively recent science, defined as 'the structural adaptation of chromosomal regions so as to register, signal or perpetuate altered activity states', and referring to heritable changes in gene expression patterns not caused by alterations in the nucleotide sequence itself $[17,18]$. Epigenetics plays a pivotal role both in mammalian development and in several pathological conditions, such as cancer and immune dysfunction. The epigenome 


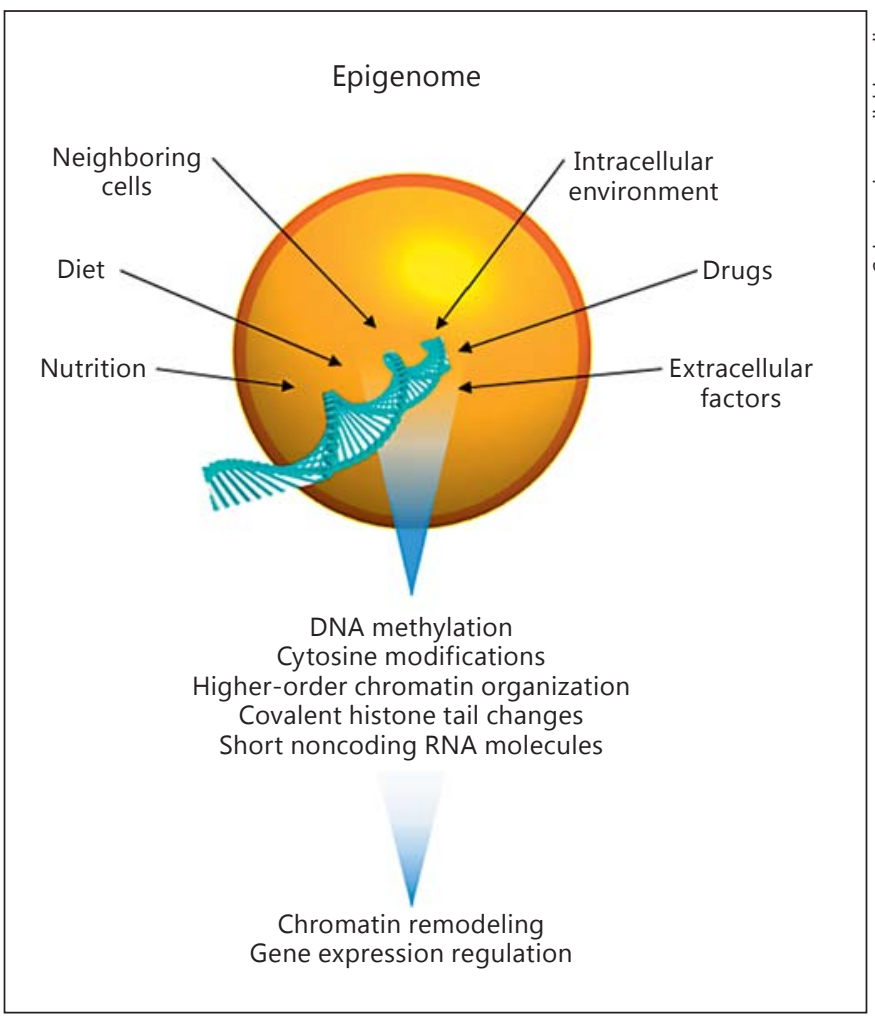

Fig. 1. Epigenetic biochemical mechanisms. Epigenomic changes in response to specific signals coming from the intracellular environment, neighboring cells and extracellular factors, such as diet, drugs and nutrition.

is crucial for the transcriptional outcome, allowing certain genes to be expressed while others cannot access the transcriptional machinery. Understanding the epigenome is critical for the comprehension of cell-typespecific gene regulation both in baseline and disease conditions [19]. The epigenome changes in response to specific signals coming from the intracellular environment, neighboring cells and extracellular factors, such as diet, drugs and nutrition. Epigenetic biochemical mechanisms include DNA methylation, cytosine modifications, covalent histone tail changes, higher-order chromatin organization and short noncoding RNA molecules, which are associated with chromatin remodeling and gene expression regulation (fig. 1). Recently, considerable attention has been paid to the role of epigenetic mechanisms and factors implied in cellular and subcellular responses associated with acute kidney injury, chronic kidney disease (CKD), heart failure and cardiovascular disease [20-31]. It is known that DNA methylation and histone modifications closely interact to control gene expression, and they may have a role in the organ cross talk [32, 33]. In particular, these mechanisms seem to be involved in the determination of gene accessibility to RNA polymerase II and to relevant transcription factors [34].

Epigenetic inheritance is responsible for a greater amount of phenotypic cellular differences in multicellular organisms [35]. This concept may explain why subjects with both similar genetic background and environmental risk factors for cardiovascular disease and/or CKD could have different clinical outcomes and manifestation of the disease [33]. In particular, several lines of evidence are pointing to the fact that epigenetic modifications might play a specific role in CKD development: smoking, mitochondrial dysfunction, hypertension and nephron number are significantly influenced by the in utero environment programming [36-38]. Furthermore, multiple studies have been performed to analyze methylation changes in peripheral blood samples obtained from healthy controls, and diabetic and CKD patients. These studies indicated modified methylation profiles in blood samples obtained from CKD patients [25-27, 3941]. Initial analyses on global DNA methylation changes have demonstrated both DNA hypo- and hypermethylation; later genome-wide analyses have identified several different loci associated with DNA methylation changes in CKD [25-27, 39-41]. Unfortunately, the interpretation of the results is difficult because of the specific cell type nature of the epigenome. Indeed, general consensus exists on the toxic effects of the uremic milieu on epigenetic gene regulation, thus perpetuating CKD-associated accelerated arteriosclerosis and cardiovascular disease [42-46].

Limited data exist regarding epigenetic mechanisms involved in the setting of acute and chronic subtypes of CRS. Unfortunately, it is still unclear how CRS risk factors are affected by histone modification, methylation and RNA interference. Recently, fascinating and promising evidence has emerged about overnutrition and CRS. Nistala et al. [47] reported that maternal and paternal malnutrition (both under- and overnutrition) may affect fetal and prenatal programming, thus predisposing the fetus to CRS development. While in utero nutrient restriction has been shown to promote hypertension, cardiovascular disease and CKD in offspring, a high birth weight is associated with an increased propensity for the development of CRS [48-54]. Collectively, it is still unclear how CRS risk factors are affected by histone modification, methylation and RNA interference. A better elucidation of the epigenetic paradigm in CRS context 
could revolutionize and change both diagnosis and treatment of this syndrome: drugs and therapies modulating epigenetic modifications could prevent and/or attenuate CRS.

\section{Small Noncoding RNAs: A Possible New Entity Implicated in Heart-Kidney Cross Talk}

Small noncoding RNAs, which are constituted by about 18-30 endogenous nucleotides, represent an alternative intrinsic resource of gene regulation. Almost 2,500 types of these molecules have been isolated in many life forms. They have been found in all human cells and they are evolutionarily well conserved. Understanding the role of these noncoding molecules both in healthy and disease conditions is crucial due to their possible association with many critical biological functions $[55,56]$. Well over half of the human transcriptome is, indeed, predicted to be under small noncoding RNA regulation [57]. Small noncoding RNAs regulate the expression of protein-coding genes through sequence-specific recognition, binding to the $3^{\prime}$ or $5^{\prime}$-untranslated region ( $3^{\prime}$-UTR) of target messenger RNA (mRNA) or promoter sequences, thus regulating mRNA levels by posttranscriptional mechanisms $[58,59]$. Partial sequence complementarity between a small noncoding RNA and its target site in a specific mRNA is often sufficient for binding [57]. Several algorithms are usually used to discover these interactions, with computational predictions suggesting that a single small noncoding RNA can potentially regulate multiple RNAs $[57,60]$. However, in vitro experimentation is always necessary to validate the predicted targets as well as the role of small noncoding RNAs in the regulation of the cell signaling pathway, cell communication and cellular phenotype [57, 60]. Moreover, the general role of these molecules in specific cellular or physiological processes can be examined by deleting or inhibiting the microRNA (miRNA)-processing machinery. There is an increasing number of reports on the regulatory roles of these RNAs, including transcriptional gene silencing/activation and posttranscriptional gene silencing events $[61,62]$. In animals, partial pairing between small noncoding RNA and mRNA target site usually results in diminished protein expression through a variety of mechanisms, such as mRNA destabilization, degradation, translational repression and even activation of gene expression $[57,63]$. Additionally, these small RNAs are secreted from cells and enter the bloodstream directed toward targeted cells, thus denoting a new communication approach in cell-cell or cell-organ signal transduction. Different tech- niques have been established to isolate small RNAs from cell-free bodily fluids, such as serum, plasma and urine [64]. Thus, small RNAs are reportedly present in the circulation and found to be stable [65]. Consistent with tissuespecific functions, many small RNAs have different biological effects depending on the cell nature. It is not unexpected, therefore, that small RNAs play an essential role as transcriptional regulators in a wide range of biological processes such as cellular differentiation, growth/proliferation, apoptosis/death, migration, stress responses, metabolism and defense [58, 66-69]. Given these diverse roles, small RNAs could be pivotal regulators in the development of disease states [66, 70]. Different noncoding RNAs exist and they have been classified into three main categories: miRNAs, small interfering RNAs and piwi-interacting RNAs on the basis of their features related to the origin, structure, associated effector proteins and biological functions [71, 72]. miRNAs have been studied more extensively. In particular, increasing evidence indicates that miRNAs might be associated with several pathological conditions, such as cardiovascular and renal diseases [6870, 73-79]. Circulating miRNAs have been demonstrated to possess different profiles in patients with heart failure, acute kidney injury and CKD when compared to controls, suggesting their possible use as innovative biomarkers for these conditions.

In the heart, miRNAs seem to be involved in the regulation of different mechanisms, including excitation-contraction, cardiac remodeling and regeneration, myocyte hypertrophy, ventricular dilatation, apoptosis and myocardial fibrosis [80, 81]. In this regard, Tijsen et al. [77] reported that miR423-5p was particularly high in the blood of patients with heart failure, and its level was related to the severity of the disease. Increased levels of miR423-5p, miR320a, miR22 and miR92b have also been found in heart failure patients [82]. Likewise, Corsten et al. [83] observed higher circulating levels of miR499 and miR122 in the setting of acute heart failure. Moreover, miR21 and miR29 are abundantly expressed in the heart and seem to regulate myocardial fibrosis by acting on mRNA of extracellular matrix proteins and TGF- $\beta_{1}[84$, 85]. Rana et al. [13] have recently reported the role of cardiac miR21 and miR29b together with the inhibition of myocardial fibrosis in myocardial infarction after lowering uremic toxin levels in a rat model of CRS. Exposure to elevated serum concentrations of indoxyl sulfate (IS) was associated with an increase in miR21 expression and a reduction in miR29b in the heart. Furthermore, a significant correlation between cardiac miR2 1 and serum levels of IS, and a significant inverse association between 
cardiac miR29b and serum levels of IS were observed. These results collectively suggest a clear role of IS in altering miRNA2 1 and miRNA29b in the heart, which leads to cardiac fibrosis [13]. Moreover, miR1, miR133, miR208, miR23a and miR199b have been demonstrated to play a major role in the development of cardiac hypertrophy, whereas miR21, miR199a, miR210 and miR494 are fundamental for myocyte survival during ischemia [86].

The kidney mostly expresses miR192, miR194, miR204, miR215 and miR216, which have been implicated in the migration and proliferation of renal cells [87, 88]. The deletion of the miRNA30 family is responsible for the decrease in renal cell numbers, vascular damage and extensive fibrosis $[74,89]$. In addition, miRNA192 has been identified as a key regulator of collagen formation in diabetic kidney disease in a mouse model, whereas in renal biopsies from patients with diabetic kidney disease, TGF- $\beta$ up-regulated miRNA192 expression in proximal tubule cells, correlating with fibrosis and a reduction in estimated glomerular filtration rate $[90,91]$. Furthermore, miR21 expression was found to be increased in proliferating tubular epithelial cells, whereas knockdown of miR21 resulted in enhanced apoptosis in these cells [92]. In an animal model, targeted deletion of the gene Dicer from the proximal tubular epithelium protects from ischemia/reperfusion-induced renal injury and is associated with changes in the expression of several miRNAs, such as miR132, miR362 and miR379 [93]. The role of miRNA in the pathogenesis of acute kidney injury is still not well understood. Lee et al. [94] have recently evaluated an integrative network of miRNAs and mRNA data by microarray analyses to discover a possible master regulator of acute kidney injury. miR122 was found to be down-regulated by cisplatin, whereas miR34a was up-regulated by the drug. In addition, miR192 and miR377 seem to be implicated in matrix deposition and fibrosis $[91,95]$, while miR200 and miR205 seem to be related to the epithelial-to-mesenchymal transition [95].

\section{The Role of EVs in the Cardiorenal Cross Talk}

As remarkable discovery, miRNAs have been found in the extracellular space and in biological fluids in a relatively stable state despite the existence of RNAse [96]. These extracellular miRNAs, excreted through various and incompletely understood pathways, may be protected from degradation by several mechanisms. The inclusion in EVs, such as microvesicles, exosomes and apo-

Molecular and Genetic Mechanisms in CRS ptotic bodies, as well as the formation of protein-miRNA complexes have been reported as possible mechanisms against RNAse degradation [69]. EVs are all cell-derived vesicles enclosed in a lipid bilayer, ranging from 30 to $2,000 \mathrm{~nm}$ in diameter depending on their origin. In fact, three main populations of EVs have been identified, according to their intracellular origin and dimension [97, 98]. EVs contain a specific subset of common proteins related to biogenesis and trafficking, as well as specific components derived from their cell or tissue of origin [99, $100]$, such as proteins and nucleic acids [101-103]. Therefore, the study of the proteome and the nucleic acid content of EVs may provide information about the cell or tissue of origin and, importantly, their physiological state. Three public online databases including all gathered information about EV content are available: EVpedia, ExoCarta and Vesiclepedia [103-106]. Exosomes are vesicles $30-150 \mathrm{~nm}$ in diameter derived from inward budding of endosomal membranes, resulting in the progressive accumulation of intraluminal vesicles within large multivesicular compartments. They are released extracellularly when these multivesicular compartments fuse with the plasma membrane $[99,107]$. Microvesicles are bigger than exosomes (100-1,000 nm) and they are produced by direct budding of the plasma membrane [108]. The first evidence of exosome-mediated transfer of mRNAs and miRNAs has recently been shown by Valadi et al. [109], who observed substantial amounts of RNA in the exosomes of mouse mast cells. Apoptotic bodies appear as a heterogeneous group of vesicles, ranging from $50 \mathrm{~nm}$ to $5 \mu \mathrm{m}$ in size and $1.16-1.28 \mathrm{~g} / \mathrm{ml}$ in buoyant density [110-112]. They contain DNA, RNA and histones, and display 'eat-me' signaling molecules, causing their phagocytosis by macrophages $[113,114]$. Due to their specific cellular content and high density, they may be distinguished from two other major vesicle populations, which show considerably more overlap [97].

Exosomes might play a pivotal role in the pathophysiology of kidney and heart diseases due to their action as mediators of intercellular communication and signaling mechanisms in the target cell, transfer of mRNAs, miRNAs and proteins, or the establishment of a way of cellular content disposal $[115,116]$. Circumstantial evidence has demonstrated, indeed, that these vesicles may be considered as molecular markers of renal dysfunction and structural injury, both in acute and chronic kidneys (i.e. diabetic nephropathy, focal segmental glomerulosclerosis and glomerulonephritis) and in graft rejection [117-124]. Exosomes are released by podocytes, pass through the renal tubule and they can be taken up by re- 
Fig. 2. EVs and the cardiorenal cross talk. The role of EVs acquires special significance in the context of CRS in which the bidirectional cross talk and interaction between heart and kidneys is known.

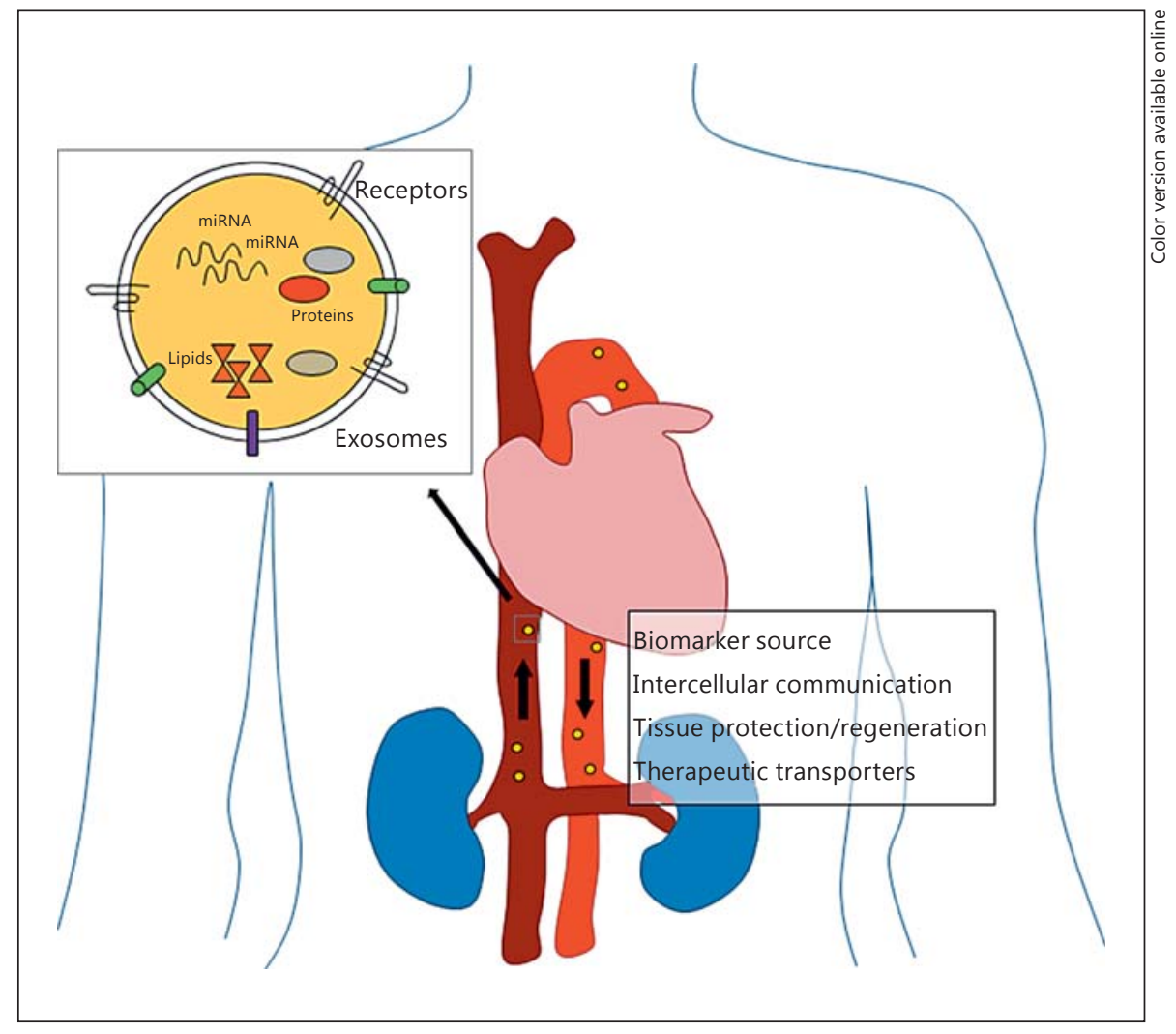

cipient epithelial cells of the collecting duct, thus influencing their function through the secretion of their content. Finally, they appear in the urine where they reflect the state of the urinary system, from podocytes to renaltubular cells, thus making them an excellent source of samples for the study of kidney physiology and pathology $[125,126]$. In the setting of cardiovascular diseases, platelets have been found to secrete exosomes, which may be involved in the complex cross talk between diverse cell types in atherosclerosis plaques [127]. Cardiomyocytes have also been shown to release exosomes able to transfer DNA and RNA to different cells [128]. However, the involvement of exosomes either in vascular diseases or in cardiovascular protection mechanisms has not been deeply investigated and fully unraveled. The role of EVs acquires special significance in the context of CRS in which the cross talk between heart and kidneys is known but not gone through. In fact, apart from being a source of potential new biomarkers, they participate in intercellular communication, in terms of protein and miRNA transfer from the origin cell to the target cell or act as functionalized messengers to ensure specific drug delivery to the desired point of action (fig. 2).

\section{Future Research}

Research on EVs is not only focused on their potential role as source of biomarkers but also as a new therapeutic tool. Taking into account the properties and functions of EVs, different clinical studies have been developed aiming to use them in therapy [112]. Unfortunately, a gold standard technique for the isolation of EVs in clinical practice is still missing. Different approaches exist, such as ultracentrifugation, filtration, immune-affinity method, aggregating agents and size exclusion chromatography. Once methodological difficulties are overcome, this research in the context of cardiorenal pathology is, therefore, more than justified. EVs are currently attracting increased attention and they constitute a promising field in this and other pathologies [14].

In the setting of acute kidney diseases, few studies have tested different sources of EVs for their therapeutic potential. Cantaluppi et al. [129] tested the effect of EVs from endothelial progenitor cells in a rat model for ischemia and reperfusion injury. The miRNA content of these vesicles seems to have a positive effect on renal tubular epithelial cells, reducing apoptosis and promoting cell 
proliferation [130]. Chen et al. [131] probed, in a mouse model, that injection of exosomal transcriptional repressor activating transcription factor 3 (ATF3), which has an anti-apoptotic effect and inhibits inflammatory responses, is able to reduce ischemia-reperfusion kidney injury. Similarly, the effect of liver stem cell EVs in the regeneration of renal-tubule injury has been suggested in the study of Herrera Sánchez et al. [132], who demonstrated the inhibitory effect of these vesicles on renal-tubular cell apoptosis in a murine model of acute kidney injury.

\section{Conclusion}

Elucidation of the cardiorenal puzzle demands for expanded knowledge of many still missing pieces. Heart-kidney cross talk has significant clinical rele- vance and the management of CRS is challenging due to the multitude and complexity of the pathophysiological interactions between these two organs. Alternative factors, such as epigenetics, prenatal programming, small noncoding RNA and EVs, might represent a new way of communication between cells and organs in the setting of cardiorenal cross talk. Nevertheless, this field of research still remains largely unexplored. Further studies are needed, because genetic mechanisms may represent very attractive therapeutic targets, thus improving clinical outcomes of patients with heart and kidney disease.

\section{Disclosure Statement}

The authors declare no conflict of interest.

\section{References}

1 Ronco C, Haapio M, House AA, Anavekar N, Bellomo R: Cardiorenal syndrome. J Am Coll Cardiol 2008;52:1527-1539.

2 Goh CY, Vizzi G, De Cal M, Ronco C: Cardiorenal syndrome: a complex series of combined heart/kidney disorders. Contrib Nephrol 2011;174:33-45.

3 McCullough PA, Kellum JA, Haase M, Muller C, Damman K, Murray PT, et al: Pathophysiology of the cardiorenal syndromes: executive summary from the eleventh consensus conference of the Acute Dialysis Quality Initiative (ADQI). Contrib Nephrol 2013;182:82-98.

4 Virzi G, Day S, de Cal M, Vescovo G, Ronco C: Heart-kidney crosstalk and role of humoral signaling in critical illness. Crit Care 2014; 18:201.

5 Fabbian F, Pala M, De Giorgi A, Scalone A, Molino C, Portaluppi F, et al: Clinical features of cardio-renal syndrome in a cohort of consecutive patients admitted to an internal medicine ward. Open Cardiovasc Med J 2011;5: 220-225.

6 Bagshaw SM, Cruz DN, Aspromonte N, Daliento L, Ronco F, Sheinfeld G, et al: Epidemiology of cardio-renal syndromes: workgroup statements from the 7th ADQI Consensus Conference. Nephrol Dial Transplant 2010;25:1406-1416.

7 Gigante A, Liberatori M, Gasperini ML, Sardo L, Di Mario F, Dorelli B, et al: Prevalence and clinical features of patients with the cardiorenal syndrome admitted to an internal medicine ward. Cardiorenal Med 2014;4:88-94.

8 Rosner MH, Ronco C, Okusa MD: The role of inflammation in the cardio-renal syndrome: a focus on cytokines and inflammatory mediators. Semin Nephrol 2012;32:70-78.
9 Virzi GM, Clementi A, de Cal M, Brocca A, Day S, Pastori S, et al: Oxidative stress: dual pathway induction in cardiorenal syndrome type 1 pathogenesis. Oxid Med Cell Longev 2015;2015:391790.

10 Virzi GM, de Cal M, Day S, Brocca A, Cruz DN, Castellani C, et al: Pro-apoptotic effects of plasma from patients with cardiorenal syndrome on human tubular cells. Am J Nephrol 2015;41:474-484.

11 Virzi GM, Torregrossa R, Cruz DN, Chionh CY, de Cal M, Soni SS, et al: Cardiorenal syndrome type 1 may be immunologically mediated: a pilot evaluation of monocyte apoptosis. Cardiorenal Med 2012;2:33-42.

12 Brocca A, Virzi GM, Pasqualin C, Pastori S, Marcante S, de Cal M, et al: Cardiorenal syndrome type 5 : in vitro cytotoxicity effects on renal tubular cells and inflammatory profile. Anal Cell Pathol (Amst) 2015;2015:469461.

13 Rana I, Kompa AR, Skommer J, Wang BH, Lekawanvijit S, Kelly DJ, et al: Contribution of microRNA to pathological fibrosis in cardio-renal syndrome: impact of uremic toxins. Physiol Rep 2015;3:e12371.

14 Gonzalez-Calero L, Martin-Lorenzo M, Alvarez-Llamas G: Exosomes: a potential key target in cardio-renal syndrome. Front Immunol 2014;5:465.

$15 \mathrm{Fu}$ Q, Cao L, Li H, Wang B, Li Z: Cardiorenal syndrome: pathophysiological mechanism, preclinical models, novel contributors and potential therapies. Chin Med J (Engl) 2014; 127:3011-3018.

16 Hatamizadeh P, Fonarow GC, Budoff MJ, Darabian S, Kovesdy CP, Kalantar-Zadeh K: Cardiorenal syndrome: pathophysiology and potential targets for clinical management. Nat Rev Nephrol 2013;9:99-111.
17 Bird A: Perceptions of epigenetics. Nature 2007;447:396-398.

18 Ko YA, Susztak K: Epigenomics: the science of no-longer-junk DNA. Why study it in chronic kidney disease? Semin Nephrol 2013; 33:354-362.

19 Ernst J, Kellis M: Interplay between chromatin state, regulator binding, and regulatory motifs in six human cell types. Genome Res 2013;23:1142-1154.

20 Bomsztyk K, Denisenko O: Epigenetic alterations in acute kidney injury. Semin Nephrol 2013;33:327-340.

21 Schena FP, Serino G, Sallustio F: MicroRNAs in kidney diseases: new promising biomarkers for diagnosis and monitoring. Nephrol Dial Transplant 2014;29:755-763.

22 Tang J, Zhuang S: Epigenetics in acute kidney injury. Curr Opin Nephrol Hypertens 2015; 24:351-358.

23 Rodriguez-Romo R, Berman N, Gomez A, Bobadilla NA: Epigenetic regulation in the acute kidney injury (AKI) to chronic kidney disease transition (CKD). Nephrology (Carlton) DOI: $10.1111 /$ nep.12521.

24 Huang J, Wan D, Li J, Chen H, Huang K, Zheng L: Histone acetyltransferase PCAF regulates inflammatory molecules in the development of renal injury. Epigenetics 2015;10:62-72.

25 Smyth LJ, McKay GJ, Maxwell AP, McKnight AJ: DNA hypermethylation and DNA hypomethylation is present at different loci in chronic kidney disease. Epigenetics 2014;9: 366-376.

26 Zawada AM, Rogacev KS, Heine GH: Clinical relevance of epigenetic dysregulation in chronic kidney disease-associated cardiovascular disease. Nephrol Dial Transplant 2013; 28:1663-1671.
Molecular and Genetic Mechanisms in CRS 
27 Witasp A, Ekstrom TJ, Lindholm B, Stenvinkel P, Schalling M, Nordfors L: Novel insights from genetic and epigenetic studies in understanding the complex uraemic phenotype. Nephrol Dial Transplant 2014;29:964-971.

28 Cao Y, Lu L, Liu M, Li XC, Sun RR, Zheng Y, et al: Impact of epigenetics in the management of cardiovascular disease: a review. Eur Rev Med Pharmacol Sci 2014;18:3097-3104.

29 Abi Khalil C: The emerging role of epigenetics in cardiovascular disease. Ther Adv Chronic Dis 2014;5:178-187.

30 Yang J, Xu WW, Hu SJ: Heart failure: advanced development in genetics and epigenetics. Biomed Res Int 2015;2015:352734.

31 Clementi A, Virzi GM, Brocca A, de Cal M, Pastori S, Clementi M, et al: Advances in the pathogenesis of cardiorenal syndrome type 3 . Oxid Med Cell Longev 2015;2015:148082.

32 Burgers WA, Fuks F, Kouzarides T: DNA methyltransferases get connected to chromatin. Trends Genet 2002;18:275-277.

33 Napoli C, Casamassimi A, Crudele V, Infante $\mathrm{T}$, Abbondanza C: Kidney and heart interactions during cardiorenal syndrome: a molecular and clinical pathogenic framework. Future Cardiol 2011;7:485-497.

34 Bataille A, Galichon P, Ziliotis MJ, Sadia I, Hertig A: Epigenetic changes during sepsis: on your marks! Crit Care 2015;19:358.

35 Portela A, Esteller M: Epigenetic modifications and human disease. Nat Biotechnol 2010;28:1057-1068.

36 Hoppe CC, Evans RG, Bertram JF, Moritz KM: Effects of dietary protein restriction on nephron number in the mouse. Am J Physiol Regul Integr Comp Physiol 2007;292:R1768-R1774.

37 Hoppe CC, Evans RG, Moritz KM, CullenMcEwen LA, Fitzgerald SM, Dowling J, et al: Combined prenatal and postnatal protein restriction influences adult kidney structure, function, and arterial pressure. Am J Physiol Regul Integr Comp Physiol 2007;292:R462R469.

38 Stangenberg S, Chen H, Wong MG, Pollock CA, Saad S: Fetal programming of chronic kidney disease: the role of maternal smoking, mitochondrial dysfunction, and epigenetic modification. Am J Physiol Renal Physiol 2015;308:F1189-F1196.

39 Sapienza C, Lee J, Powell J, Erinle O, Yafai F, Reichert J, et al: DNA methylation profiling identifies epigenetic differences between diabetes patients with ESRD and diabetes patients without nephropathy. Epigenetics 2011;6:20-28.

40 Geisel J, Schorr H, Heine GH, Bodis M, Hubner U, Knapp JP, et al: Decreased p66Shc promoter methylation in patients with end-stage renal disease. Clin Chem Lab Med 2007;45 1764-1770.

41 Stenvinkel P, Karimi M, Johansson S, Axelsson J, Suliman M, Lindholm B, et al: Impact of inflammation on epigenetic DNA methylation - a novel risk factor for cardiovascular disease? J Intern Med 2007;261:488-499.
42 Stenvinkel P, Carrero JJ, Axelsson J, Lindholm B, Heimburger O, Massy Z: Emerging biomarkers for evaluating cardiovascular risk in the chronic kidney disease patient: how do new pieces fit into the uremic puzzle? Clin J Am Soc Nephrol 2008;3:505-521.

43 Stenvinkel P, Ekstrom TJ: Epigenetics and the uremic phenotype: a matter of balance. Contrib Nephrol 2008;161:55-62.

44 Dwivedi RS, Herman JG, McCaffrey TA, Raj DS: Beyond genetics: epigenetic code in chronic kidney disease. Kidney Int 2011;79: 23-32.

45 Liu M, Li XC, Lu L, Cao Y, Sun RR, Chen S, et al: Cardiovascular disease and its relationship with chronic kidney disease. Eur Rev Med Pharmacol Sci 2014;18:2918-2926.

46 Ordovas JM, Smith CE: Epigenetics and cardiovascular disease. Nat Rev Cardiol 2010;7: 510-519.

47 Nistala R, Hayden MR, Demarco VG, Henriksen EJ, Lackland DT, Sowers JR: Prenatal programming and epigenetics in the genesis of the cardiorenal syndrome. Cardiorenal Med 2011;1:243-254.

48 Gluckman PD, Hanson MA, Buklijas T, Low FM, Beedle AS: Epigenetic mechanisms that underpin metabolic and cardiovascular diseases. Nat Rev Endocrinol 2009;5:401-408.

49 Boney CM, Verma A, Tucker R, Vohr BR: Metabolic syndrome in childhood: association with birth weight, maternal obesity, and gestational diabetes mellitus. Pediatrics 2005; 115:e290-e296.

50 Heerwagen MJ, Miller MR, Barbour LA, Friedman JE: Maternal obesity and fetal metabolic programming: a fertile epigenetic soil. Am J Physiol Regul Integr Comp Physiol 2010;299:R711-R722.

51 Freeman DJ: Effects of maternal obesity on fetal growth and body composition: implications for programming and future health. Semin Fetal Neonatal Med 2010;15:113-118.

52 Sowers JR, Whaley-Connell A, Hayden MR: The role of overweight and obesity in the cardiorenal syndrome. Cardiorenal Med 2011;1: 5-12.

53 Pulakat L, Demarco VG, Whaley-Connell A, Sowers JR: The impact of overnutrition on insulin metabolic signaling in the heart and the kidney. Cardiorenal Med 2011;1:102-112.

54 Pulakat L, DeMarco VG, Ardhanari S, Chockalingam A, Gul R, Whaley-Connell A, et al: Adaptive mechanisms to compensate for overnutrition-induced cardiovascular abnormalities. Am J Physiol Regul Integr Comp Physiol 2011;301:R885-R895.

55 Sun BK, Tsao H: Small RNAs in development and disease. J Am Acad Dermatol 2008;59: 725-737.

56 Pritchard CC, Cheng HH, Tewari M: MicroRNA profiling: approaches and considerations. Nat Rev Genet 2012;13:358-369.

57 Pasquinelli AE: MicroRNAs and their targets: recognition, regulation and an emerging reciprocal relationship. Nat Rev Genet 2012;13: 271-282.
58 Khare S, Zhang Q, Ibdah JA: Epigenetics of hepatocellular carcinoma: role of microRNA. World J Gastroenterol 2013;19:5439-5445.

59 Aalto AP, Pasquinelli AE: Small non-coding RNAs mount a silent revolution in gene expression. Curr Opin Cell Biol 2012;24:333340 .

60 Witkos TM, Koscianska E, Krzyzosiak WJ: Practical aspects of microRNA target prediction. Curr Mol Med 2011;11:93-109.

61 Bartel DP: MicroRNAs: genomics, biogenesis, mechanism, and function. Cell 2004;116: 281-297.

62 Azimzadeh Jamalkandi S, Azadian E, Masoudi-Nejad A: Human RNAi pathway: crosstalk with organelles and cells. Funct Integr Genomics 2014;14:31-46.

63 Huntzinger E, Izaurralde E: Gene silencing by microRNAs: contributions of translational repression and mRNA decay. Nat Rev Genet 2011;12:99-110.

64 Gilad S, Meiri E, Yogev Y, Benjamin S, Lebanony D, Yerushalmi N, et al: Serum microRNAs are promising novel biomarkers. PLoS One 2008;3:e3148.

65 Mitchell PS, Parkin RK, Kroh EM, Fritz BR, Wyman SK, Pogosova-Agadjanyan EL, et al: Circulating microRNAs as stable blood-based markers for cancer detection. Proc Natl Acad Sci USA 2008; 105:10513-10518.

66 Wang Y, Stricker HM, Gou D, Liu L: MicroRNA: past and present. Front Biosci 2007;12: 2316-2329.

67 Zhang C: MicroRNomics: a newly emerging approach for disease biology. Physiol Genomics 2008;33:139-147.

68 Zhang C: Novel functions for small RNA molecules. Curr Opin Mol Ther 2009;11:641-651.

69 Lorenzen JM, Batkai S, Thum T: Regulation of cardiac and renal ischemia-reperfusion injury by microRNAs. Free Radic Biol Med 2013;64:78-84

70 Friedman JM, Jones PA: MicroRNAs: critical mediators of differentiation, development and disease. Swiss Med Wkly 2009;139:466472.

71 Farazi TA, Juranek SA, Tuschl T: The growing catalog of small RNAs and their association with distinct Argonaute/Piwi family members. Development 2008;135:1201-1214.

72 Kaikkonen MU, Lam MT, Glass CK: Noncoding RNAs as regulators of gene expression and epigenetics. Cardiovasc Res 2011;90:430440

73 Vettori S, Gay S, Distler O: Role of microRNAs in fibrosis. Open Rheumatol J 2012;6: 130-139.

74 Lorenzen JM, Thum T: Circulating and urinary microRNAs in kidney disease. Clin J Am Soc Nephrol 2012;7:1528-1533.

75 Lorenzen JM, Kielstein JT, Hafer C, Gupta SK, Kumpers P, Faulhaber-Walter R, et al: Circulating miR-210 predicts survival in critically ill patients with acute kidney injury. Clin J Am Soc Nephrol 2011;6:1540-1546. 
76 van Rooij E, Sutherland LB, Liu N, Williams AH, McAnally J, Gerard RD, et al: A signature pattern of stress-responsive microRNAs that can evoke cardiac hypertrophy and heart failure. Proc Natl Acad Sci USA 2006; 103:1825518260.

77 Tijsen AJ, Creemers EE, Moerland PD, de Windt LJ, van der Wal AC, Kok WE, et al: MiR423-5p as a circulating biomarker for heart failure. Circ Res 2010;106:1035-1039.

78 Wijnen WJ, van der Made I, van den Oever S, Hiller M, de Boer BA, Picavet DI, et al: Cardiomyocyte-specific miRNA-30c overexpression causes dilated cardiomyopathy. PLoS One 2014;9:e96290.

79 Kato M, Arce L, Natarajan R: MicroRNAs and their role in progressive kidney diseases. Clin J Am Soc Nephrol 2009;4:1255-1266.

80 Braunwald E: Heart failure. JACC Heart Fail 2013;1:1-20.

81 Eulalio A, Mano M, Dal Ferro M, Zentilin L, Sinagra G, Zacchigna $S$, et al: Functional screening identifies miRNAs inducing cardiac regeneration. Nature 2012;492:376-381.

82 Goren Y, Kushnir M, Zafrir B, Tabak S, Lewis BS, Amir O: Serum levels of microRNAs in patients with heart failure. Eur J Heart Fail 2012;14:147-154.

83 Corsten MF, Dennert R, Jochems S, Kuznetsova $T$, Devaux $Y$, Hofstra L, et al: Circulating microRNA-208b and microRNA-499 reflect myocardial damage in cardiovascular disease. Circ Cardiovasc Genet 2010;3:499-506.

84 van Rooij E, Sutherland LB, Thatcher JE, DiMaio JM, Naseem RH, Marshall WS, et al: Dysregulation of microRNAs after myocardial infarction reveals a role of miR-29 in cardiac fibrosis. Proc Natl Acad Sci USA 2008; 105:13027-13032.

85 Liang H, Zhang C, Ban T, Liu Y, Mei L, Piao $\mathrm{X}$, et al: A novel reciprocal loop between microRNA-21 and TGFbetaRIII is involved in cardiac fibrosis. Int J Biochem Cell Biol 2012; 44:2152-2160.

86 Han M, Toli J, Abdellatif M: MicroRNAs in the cardiovascular system. Curr Opin Cardiol 2011:26:181-189.

87 Tian Z, Greene AS, Pietrusz JL, Matus IR, Liang M: MicroRNA-target pairs in the rat kidney identified by microRNA microarray, proteomic, and bioinformatic analysis. Genome Res 2008;18:404-411.

88 Ardekani AM, Naeini MM: The role of microRNAs in human diseases. Avicenna J Med Biotechnol 2010;2:161-179.

89 Li JY, Yong TY, Michael MZ, Gleadle JM: Review: the role of microRNAs in kidney disease. Nephrology (Carlton) 2010;15:599608.

90 Kato M, Zhang J, Wang M, Lanting L, Yuan H, Rossi JJ, et al: MicroRNA-192 in diabetic kidney glomeruli and its function in TGF-beta-induced collagen expression via inhibition of E-box repressors. Proc Natl Acad Sci USA 2007;104:3432-3437.
91 Krupa A, Jenkins R, Luo DD, Lewis A, Phillips A, Fraser D: Loss of microRNA-192 promotes fibrogenesis in diabetic nephropathy. J Am Soc Nephrol 2010;21:438-447.

92 Godwin JG, Ge X, Stephan K, Jurisch A, Tullius SG, Iacomini J: Identification of a microRNA signature of renal ischemia reperfusion injury. Proc Natl Acad Sci USA 2010; 107:14339-14344

93 Wei Q, Bhatt K, He HZ, Mi QS, Haase VH, Dong Z: Targeted deletion of Dicer from proximal tubules protects against renal ischemia-reperfusion injury. J Am Soc Nephrol 2010;21:756-761.

94 Lee CG, Kim JG, Kim HJ, Kwon HK, Cho IJ, Choi DW, et al: Discovery of an integrative network of microRNAs and transcriptomics changes for acute kidney injury. Kidney Int 2014;86:943-953.

95 Saal S, Harvey SJ: MicroRNAs and the kidney: coming of age. Curr Opin Nephrol Hypertens 2009;18:317-323.

96 Gupta SK, Bang C, Thum T: Circulating microRNAs as biomarkers and potential paracrine mediators of cardiovascular disease. Circ Cardiovasc Genet 2010;3:484-488.

97 Kooijmans SA, Vader P, van Dommelen SM, van Solinge WW, Schiffelers RM: Exosome mimetics: a novel class of drug delivery systems. Int J Nanomedicine 2012;7:152515241.

98 Camussi G, Deregibus MC, Bruno S, Cantaluppi V, Biancone L: Exosomes/microvesicles as a mechanism of cell-to-cell communication. Kidney Int 2010;78:838-848.

99 Mathivanan S, Lim JW, Tauro BJ, Ji H, Moritz RL, Simpson RJ: Proteomics analysis of A33 immunoaffinity-purified exosomes released from the human colon tumor cell line LIM1215 reveals a tissue-specific protein signature. Mol Cell Proteomics 2010;9:197208.

100 Raposo G, Stoorvogel W: Extracellular vesicles: exosomes, microvesicles, and friends. J Cell Biol 2013;200:373-383.

101 Wang Z, Hill S, Luther JM, Hachey DL, Schey KL: Proteomic analysis of urine exosomes by multidimensional protein identification technology (MudPIT). Proteomics 2012;12:329-338.

102 Lazaro-Ibanez E, Sanz-Garcia A, Visakorpi T, Escobedo-Lucea C, Siljander P, AyusoSacido A, et al: Different gDNA content in the subpopulations of prostate cancer extracellular vesicles: apoptotic bodies, microvesicles, and exosomes. Prostate 2014;74:13791390.

103 Wang D, Sun W: Urinary extracellular microvesicles: isolation methods and prospects for urinary proteome. Proteomics 2014;14: 1922-1932.

104 Simpson RJ, Kalra H, Mathivanan S: ExoCarta as a resource for exosomal research. J Extracell Vesicles DOI: 10.3402/jev.v1i0.18374.
105 Mathivanan S, Fahner CJ, Reid GE, Simpson RJ: ExoCarta 2012: database of exosomal proteins, RNA and lipids. Nucleic Acids Res 2012;40(database issue):D1241-D1244.

106 Kim DK, Lee J, Kim SR, Choi DS, Yoon YJ Kim JH, et al: EVpedia: a community web portal for extracellular vesicles research. Bioinformatics 2015;31:933-939.

107 Kowal J, Tkach M, Thery C: Biogenesis and secretion of exosomes. Curr Opin Cell Biol 2014;29:116-125.

108 Ohno S, Ishikawa A, Kuroda M: Roles of exosomes and microvesicles in disease pathogenesis. Adv Drug Deliv Rev 2013;65:398-401.

109 Valadi H, Ekstrom K, Bossios A, Sjostrand M, Lee JJ, Lotvall JO: Exosome-mediated transfer of mRNAs and microRNAs is a novel mechanism of genetic exchange between cells. Nat Cell Biol 2007;9:654-659.

110 Hristov M, Erl W, Linder S, Weber PC: Apoptotic bodies from endothelial cells enhance the number and initiate the differentiation of human endothelial progenitor cells in vitro. Blood 2004;104:2761-2766.

111 Cline AM, Radic MZ: Apoptosis, subcellular particles, and autoimmunity. Clin Immunol 2004; 112:175-182.

112 Thery C, Ostrowski M, Segura E: Membrane vesicles as conveyors of immune responses. Nat Rev Immunol 2009;9:581-593.

113 Schiller M, Bekeredjian-Ding I, Heyder P, Blank N, Ho AD, Lorenz HM: Autoantigens are translocated into small apoptotic bodies during early stages of apoptosis. Cell Death Differ 2008;15:183-191.

114 Gregory CD, Pound JD: Microenvironmental influences of apoptosis in vivo and in vitro. Apoptosis 2010;15:1029-1049.

115 Hogan MC, Manganelli L, Woollard JR, Masyuk AI, Masyuk TV, Tammachote R, et al: Characterization of PKD protein-positive exosome-like vesicles. J Am Soc Nephrol 2009;20:278-288.

116 Borges FT, Melo SA, Ozdemir BC, Kato N, Revuelta I, Miller CA, et al: TGF- $\beta 1$-containing exosomes from injured epithelial cells activate fibroblasts to initiate tissue regenerative responses and fibrosis. J Am Soc Nephrol 2013;24:385-392.

117 Miranda KC, Bond DT, McKee M, Skog J, Paunescu TG, Da Silva N, et al: Nucleic acids within urinary exosomes/microvesicles are potential biomarkers for renal disease. Kidney Int 2010;78:191-199.

118 Zhou H, Cheruvanky A, Hu X, Matsumoto T, Hiramatsu N, Cho ME, et al: Urinary exosomal transcription factors, a new class of biomarkers for renal disease. Kidney Int 2008;74:613-621.

119 Gatti S, Bruno S, Deregibus MC, Sordi A, Cantaluppi V, Tetta C, et al: Microvesicles derived from human adult mesenchymal stem cells protect against ischaemia-reperfusioninduced acute and chronic kidney injury. Nephrol Dial Transplant 2011;26:1474-1483. 
120 Lv LL, Cao YH, Ni HF, Xu M, Liu D, Liu H, et al: MicroRNA-29c in urinary exosome/ microvesicle as a biomarker of renal fibrosis. Am J Physiol Renal Physiol 2013;305:F1220F1227.

121 Erdbrugger U, Le TH: Extracellular vesicles in renal diseases: more than novel biomarkers? J Am Soc Nephrol 2015;27:12-26.

122 Faure V, Dou L, Sabatier F, Cerini C, Sampol J, Berland Y, et al: Elevation of circulating endothelial microparticles in patients with chronic renal failure. J Thromb Haemost 2006;4:566-573.

123 Moon PG, Lee JE, You S, Kim TK, Cho JH, Kim IS, et al: Proteomic analysis of urinary exosomes from patients of early IgA nephropathy and thin basement membrane nephropathy. Proteomics 2011;11:2459-2475.

124 Zubiri I, Posada-Ayala M, Sanz-Maroto A, Calvo E, Martin-Lorenzo M, Gonzalez-Calero L, et al: Diabetic nephropathy induces changes in the proteome of human urinary exosomes as revealed by label-free comparative analysis. J Proteomics 2014;96:92-102.
125 Salih M, Zietse R, Hoorn EJ: Urinary extracellular vesicles and the kidney: biomarkers and beyond. Am J Physiol Renal Physiol 2014;306:F1251-F1259.

126 Prunotto M, Farina A, Lane L, Pernin A, Schifferli J, Hochstrasser DF, et al: Proteomic analysis of podocyte exosome-enriched fraction from normal human urine. J Proteomics 2013;82:193-229.

127 Heijnen HF, Schiel AE, Fijnheer R, Geuze HJ, Sixma JJ: Activated platelets release two types of membrane vesicles: microvesicles by surface shedding and exosomes derived from exocytosis of multivesicular bodies and alpha-granules. Blood 1999;94:3791-3799.

128 Waldenstrom A, Genneback N, Hellman U, Ronquist G: Cardiomyocyte microvesicles contain DNA/RNA and convey biological messages to target cells. PLoS One 2012; 7:e34653.
129 Cantaluppi V, Gatti S, Medica D, Figliolini F, Bruno S, Deregibus MC, et al: Microvesicles derived from endothelial progenitor cells protect the kidney from ischemia-reperfusion injury by microRNA-dependent reprogramming of resident renal cells. Kidney Int 2012;82:412-427.

130 Bitzer M, Ben-Dov IZ, Thum T: Microparticles and microRNAs of endothelial progenitor cells ameliorate acute kidney injury. Kidney Int 2012;82:375-377.

131 Chen HH, Lai PF, Lan YF, Cheng CF, Zhong WB, Lin YF, et al: Exosomal ATF3 RNA attenuates pro-inflammatory gene $\mathrm{MCP}-1$ transcription in renal ischemia-reperfusion. J Cell Physiol 2014;229:1202-1211.

132 Herrera Sanchez MB, Bruno S, Grange C, Tapparo M, Cantaluppi V, Tetta C, et al: Human liver stem cells and derived extracellular vesicles improve recovery in a murine model of acute kidney injury. Stem Cell Res Ther 2014;5:124. 